\title{
Spatial ecology, phenological variability and moulting patterns of the Endangered Atlantic petrel Pterodroma incerta
}

\author{
Marina Pastor-Prieto ${ }^{1, *}$, Raül Ramos ${ }^{1}$, Zuzana Zajková ${ }^{1,2}$, \\ José Manuel Reyes-González ${ }^{1}$, Manuel L. Rivas ${ }^{1}$, Peter G. Ryan ${ }^{3}$, Jacob González-Solís ${ }^{1}$ \\ ${ }^{1}$ Institut de Recerca de la Biodiversitat (IRBio) and Departament de Biologia Evolutiva, \\ Ecologia i Ciències Ambientals (BEECA), Universitat de Barcelona, 08028 Barcelona, Spain \\ ${ }^{2}$ Center for Advanced Studies of Blanes (CEAB-CSIC), 17300 Girona, Spain \\ ${ }^{3}$ FitzPatrick Institute of African Ornithology, DST-NRF Centre of Excellence, University of Cape Town, Rondebosch 7701, \\ South Africa
}

\begin{abstract}
Insights into the year-round movements and behaviour of seabirds are essential to better understand their ecology and to evaluate possible threats at sea. The Atlantic petrel Pterodroma incerta is an Endangered gadfly petrel endemic to the South Atlantic Ocean, with virtually the entire population breeding on Gough Island (Tristan da Cunha archipelago). We describe adult phenology, habitat preferences and at-sea activity patterns for each phenological phase of the annual cycle and refine current knowledge about its distribution, by using light-level geolocators on 13 adults over 1-3 consecutive years. We also ascertained moulting pattern through stable isotope analysis (SIA) of nitrogen and carbon in feathers from 8 carcasses. On average, adults started their post-breeding migration on 25 December, taking $10 \mathrm{~d}$ to reach their non-breeding areas on the South American shelf slope. The pre-breeding migration started around 11 April and took $5 \mathrm{~d}$. From phenological data, we found evidence of carry-over effects between successive breeding periods. The year-round distribution generally coincided with the potential distribution obtained from habitat modelling, except during the non-breeding and pre-laying exodus periods, when birds only used the western areas of the South Atlantic. Moulting occurred during the nonbreeding period, when birds spent more time on the water, and results from SIA helped us to distinguish feathers grown around Gough Island from those grown in the non-breeding area. Overall, our results bring important new insights into the spatial ecology of this Endangered seabird, which should help improve conservation strategies in the South Atlantic Ocean.
\end{abstract}

KEY WORDS: Atlantic petrel - Year-round movements - At-sea behaviour - Carry-over effects · Patagonian Shelf

\section{INTRODUCTION}

Seabirds are becoming increasingly threatened worldwide, and their populations are subject to a variety of threats both on land, where they breed, and at sea, where they rest and forage throughout the year (Croxall et al. 2012, Lewison et al. 2012). Key threats affecting seabird populations include intro-

*Corresponding author: marina.pastor6@gmail.com duction of alien invasive predators to their breeding locations, pollution and habitat degradation, interactions with commercial fisheries, climate change and disease (Lucas \& MacGregor 2006, Olmos et al. 2006, Grémillet \& Boulinier 2009, Hilton \& Cuthbert 2010, Uhart et al. 2018, Philpot et al. 2019). Especially in the case of oceanic seabirds, their sensitive life history traits such as long life, delayed first breeding,

(C) The authors 2019. Open Access under Creative Commons by Attribution Licence. Use, distribution and reproduction are unrestricted. Authors and original publication must be credited. 
single egg per breeding attempt and strong mate fidelity (Warham 1996, Bried et al. 2003, Rodríguez et al. 2019) make them particularly prone to environmental and human perturbations, which have contributed to their current population declines and poor conservation status (González-Solís \& Shaffer 2009, Croxall et al. 2012).

In addition to long-lasting detrimental effects on population dynamics, individual life histories are also shaped by events occurring in geographically disparate places during the breeding, migration and non-breeding periods (Norris \& Marra 2007). There is mounting evidence of carry-over effects (i.e. processes that influence individual performance in a subsequent season) from the breeding to the nonbreeding period, suggesting that migratory, nonbreeding and moulting decisions made by individuals are influenced by their success in previous breeding attempts (Catry et al. 2013). Thus, taking into account the variability of breeding efforts within a population seems advisable when trying to define phenology and year-round distributions of long-lived species.

Gadfly petrels Pterodroma spp. are the largest genus of oceanic seabirds, with most species endemic to isolated oceanic archipelagos (Hilton \& Cuthbert 2010, Croxall et al. 2012). Due to the remote location of their breeding colonies, many aspects of gadfly petrels' ecology remain poorly known (Rodríguez et al. 2019). Few novel studies have generally described their at-sea distribution, showing long-range movements across ocean basins (Rayner et al. 2008, Jodice et al. 2015, Krüger et al. 2016, Ramos et al. 2016, 2017, Clay et al. 2017, Leal et al. 2017).

The Atlantic petrel Pterodroma incerta is a medium-sized procellariiform seabird (420-720 g), with a year-round distribution largely confined to the South Atlantic Ocean (Enticott 1991, Orgeira 2001, Cuthbert 2004). The species breeds during the austral winter; observations at the breeding islands indicate that they arrive at the colony from midMarch onwards, laying a single egg in June-July, with chicks fledging in December (Richardson 1984, Cuthbert 2004). Virtually the entire population, estimated at approximately 1 million pairs, breeds at Gough Island $\left(40^{\circ} 20^{\prime} \mathrm{S}, 9^{\circ} 53^{\prime} \mathrm{W}\right)$ (Cuthbert 2004, Flood \& Fisher 2013, Rexer-Huber et al. 2014). In the 1970 s, a small remnant population bred on Tristan da Cunha, but the introduction of alien predators, inland habitat modification and hunting by islanders contributed to its presumed extinction as breeder (Richardson 1984, Cuthbert 2004, BirdLife International 2017a). A few pairs also breed on the eastern plateau of Inaccessible Island (Flood \& Fisher 2013, P. G. Ryan unpubl. data). The Atlantic petrel is listed as Endangered by the IUCN due to its extremely small breeding range and the high rate of chick predation by introduced house mice Mus musculus, which has caused the population decline and may even lead to its extinction, if mice are not eradicated from Gough Island (Cuthbert et al. 2013, Dilley et al. 2015, BirdLife International 2017a, Caravaggi et al. 2019).

The poor conservation status of the Atlantic petrel calls for new insights to better understand the species' ecology and guide conservation actions. Most knowledge of its distribution at sea comes from shipbased sightings (Enticott 1991, Orgeira 2001). More recently, its general phenology and distribution were summarized together with other gadfly petrels species using tracking data (Ramos et al. 2017). However, Ramos et al. (2017) did not include detailed descriptions on its phenology and spatial ecology, the factors influencing migration schedules within the population or other important aspects of its at-sea ecology, such as habitat preferences, at-sea activity patterns and moulting strategies.

This study extends our knowledge about the spatial ecology of adult Atlantic petrels. Our first aim was using geolocation-immersion data to assess in detail phenological phases, at-sea distribution, marine habitat preferences and activity patterns yearround. Second, we explored whether breeding success might lead to carry-over effects regarding phenology, behaviour or distribution, as previously found in a number of species (Catry et al. 2013, Phillips et al. 2017, Ramos et al. 2018). Since Atlantic petrels suffer high rates of breeding failure (up to $87 \%$ rate of chick predation by introduced house mice; Wanless et al. 2007, Cuthbert et al. 2013, Dilley et al. 2015), we expected to detect, from geolocator data, a relatively high number of birds not returning to the colony during the breeding season to feed their chick due to breeding failure. We would then expect these failed-at-breeding birds, leaving the colony earlier than the remaining breeders, to adjust their annual phenological calendar. Finally, we investigated moulting patterns by performing stable isotope analysis (SIA) on feathers from dead specimens. We would expect feathers moulted close to the breeding grounds to show smaller variability in the isotopic values among individuals than feathers moulted in the wintering areas, since in the latter case a larger spatial segregation of the individual wintering areas would also lead to the integration of disparate baseline isotopic levels in their feathers. 


\section{MATERIALS AND METHODS}

\subsection{Tag deployment and data filtering}

We deployed light-level geolocators (models Mk13, Mk14 and Mk19; Biotrack) attached to a PVC ring with cable ties to the tarsus of breeding Atlantic petrels during the incubation period. Between July and August of 2010, 2011 and 2012, we deployed 42 geolocators $(21,16$ and 5, respectively) on 33 Atlantic petrels attending burrows near the research station at Gough Island. Sex of birds was unknown. Some individuals were tagged in more than 1 yr. Over $3 \mathrm{yr}$ after deployment, 26 of these 33 birds were recaptured, but 5 had lost the device. From the 21 geolocators recovered, 13 provided data. Overall, we gathered tracks from 9 individuals for $1 \mathrm{yr}, 3$ individuals for $2 \mathrm{yr}$ and 1 individual for $3 \mathrm{yr}$, resulting in 18 year-round tracks from 13 birds. This data set is already included in Ramos et al. (2017) to provide a general distribution and phenology of the species. Here, we analyzed these data in more detail, to provide information on habitat preferences, moulting strategies and activity patterns.

Geolocators measure light levels every 1 min and record the maximum value every 5 (model Mk19) or 10 min (models Mk13 and Mk14; Afanasyev 2004). Based on photoperiod and sunrise and sunset times, 2 locations per day can be inferred (one to local midday and the other to local midnight) with an average $( \pm \mathrm{SD})$ accuracy of $\sim 186 \pm 114 \mathrm{~km}$ (Phillips et al. 2004). Light level curves were supervised using TransEdit from BASTrack software (British Antarctic Survey, BAS). Geolocators were calibrated for $\sim 1 \mathrm{wk}$ before deployment outside the Gough Island research station. We used calibration data to calculate sun elevation angle for each device $\left(-3.30 \pm 0.44^{\circ}\right)$ and applied a threshold value of 20 to estimate sunrise and sunset times. We removed all locations derived from light curves presenting interferences at sunrise or sunset. Those erroneous locations inside a window of $20 \mathrm{~d}$ on either side of each equinox (Afanasyev 2004) were also removed, as latitude cannot be inferred by light-level geolocation for these periods. We considered locations with flying speeds higher than $55 \mathrm{~km} \mathrm{~h}^{-1}$ sustained over a $48 \mathrm{~h}$ period to be unrealistic and thus they were also removed. The final data set for further analysis contained $67 \%$ of all locations and is available in the Seabird Tracking Database of BirdLife International (http:// seabirdtracking.org/mapper/?dataset_id=966; BirdLife International 2017b).

\subsection{Phenology and spatial distribution}

Phenology was determined for each year-round trip by visually inspecting filtered locations in BirdTracker software (BAS) and confirmed using conductivity data, inferred from saltwater immersion data (see Section 2.3). At this step, unfiltered locations were used to inform longitudinal movements and determine phenology around the equinoxes, because longitude remains reliable (Hill 1994). Departure and arrival dates from breeding and non-breeding grounds were assessed visually. Departures were identified as the first day that any location was outside the cluster of locations from the previous $10 \mathrm{~d}$ that was followed by a clearly directed movement away from this area. Similarly, arrivals were assessed as the first day any location was inside the cluster of locations, preceded by a directed movement towards that area. Regarding incubation, only entire incubation periods were considered (data from 5 birds), excluding those that were not fully recorded because of the dates of deployment or recovery of devices. We defined an incubation bout as consecutive days without light and with no immersion records preceded and followed by light and immersion records. We inferred chick-rearing when birds made frequent brief visits to the colony at night, without immersion data during several hours, characteristic of this period (Ojowski et al. 2001). Each visit took place only during night, and consecutive visits were typically separated by several days with immersion records (night and day) at sites where foraging to provision the chick presumably occurred. These sites were far enough away from the colony to consider that those birds did not visit the colony on consecutive nights. We identified the onset date and duration of the following phenological phases: post-breeding migration, non-breeding, pre-breeding migration, pre-breeding (i.e. from arrival at the colony to prelaying exodus), pre-laying exodus (i.e. period at-sea that extends from mating to egg laying), incubation and chick-rearing.

Once those events were identified, we evaluated their variability among the year-round trips recorded. A preliminary visual exploration of changes in longitude suggested the existence of 2 phenological groups (see Fig. S1 in the Supplement at www.intres.com/articles/suppl/n040p189_supp.pdf). To typify them objectively, we applied a multivariate hierarchical clustering analysis using the function 'hclust' and the method 'ward.D2' from 'stats' package in R ( $\mathrm{R}$ Core Team 2017). We considered 7 input variables: the onset of post-breeding migration, nonbreeding, pre-breeding migration, pre-breeding, 
pre-laying exodus, incubation (all these dates were included in statistical analyses as the number of days since January 1st) and the duration (in days) of the non-breeding period (Fig. 1A). The start of chickrearing was not included because 3 birds performed post-breeding migration immediately after incuba- tion, presumably because their breeding attempt failed during incubation or around hatching (many chicks are killed by mice within hours of hatching; Dilley et al. 2015). Variables were $z$-transformed prior to analysis. We performed a silhouette analysis, using the function 'silhouette' in the R package 'clus-
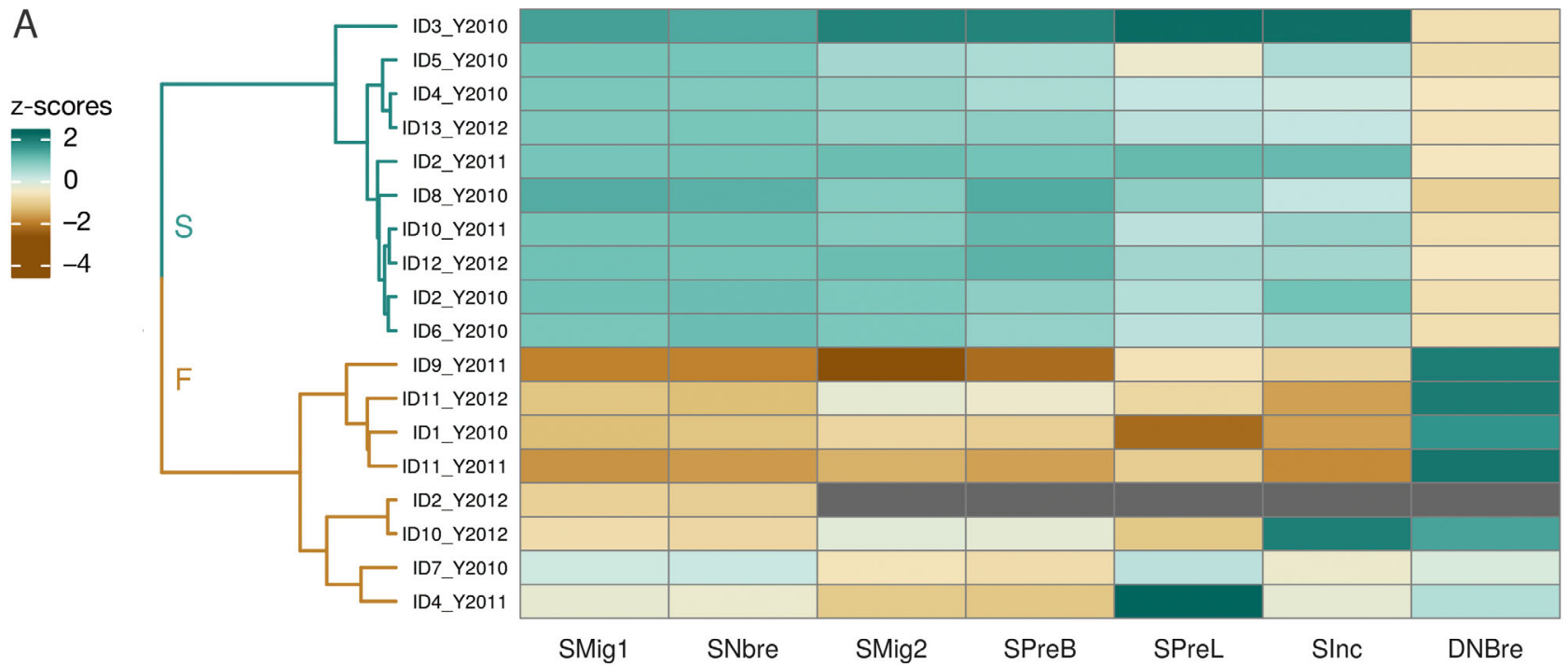

B
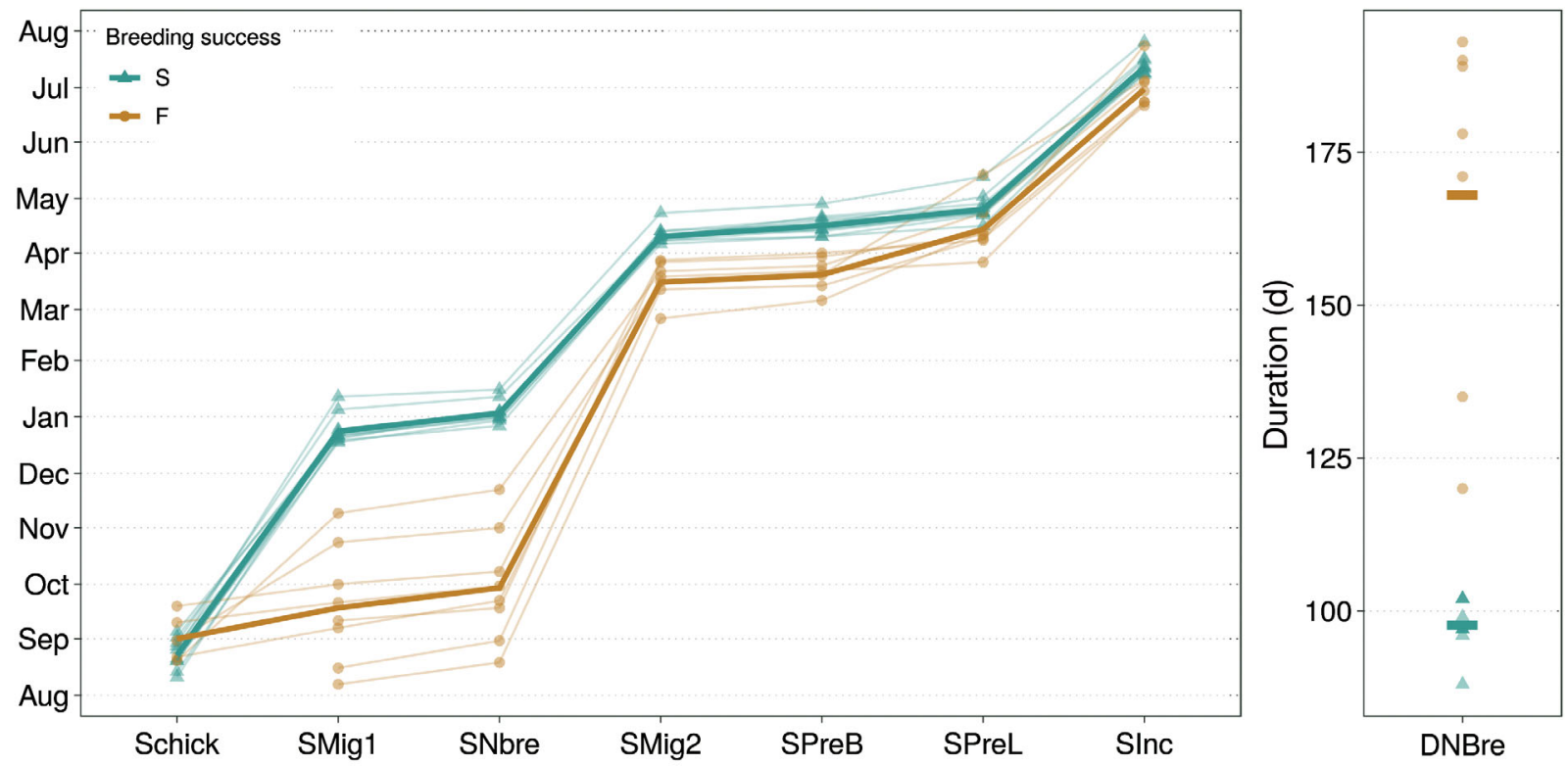

Fig. 1. Hierarchical clustering analysis of 7 scaled phenological variables of Atlantic petrels. (A) Two groups, assigned as successful (S) and failed (F) breeders, were identified applying hierarchical clustering analysis on 7 phenological variables: starting dates of post-breeding migration (SMig1), non-breeding (SNbre), pre-breeding migration (SMig2), pre-breeding (SPreB), pre-laying exodus (SPreL), incubation (SInc) and duration of non-breeding (DNBre); variables were $z$-transformed prior to analysis. Each row represents individual phenology identified by track ID (birdID_year); cell colour gradient reflects the value of the $z$-transformed variable; dark grey shaded cells: missing values. See Fig. S2 for results of silhouette analysis of this hierarchical clustering. (B) Phenology of adults (successful and failed breeders separately) tracked with geolocators from Gough Island. Thick lines: mean values of each group; thin lines: individual phenologies (see Fig. S3). Note that starting dates of chick-rearing (Schick) are detailed here, but were not included in the hierarchical clustering analysis because 3 birds performed post-breeding migration immediately after incubation, presumably because they failed either during incubation 
ter' (Maechler et al. 2017), to evaluate within-cluster consistency, i.e. how similar each sample was to the others assigned to the same cluster (Fig. S2) (Rousseeuw 1987). Clustering results showed 2 welldefined phenological groups, presumably related to breeding success (Fig. 1A,B, but see Section 3.1, Figs. S2 \& S3 and Section 4 for the rationale of this designation), so we termed these groups successful and failed breeders. We tested for differences in phenology between these groups using a MannWhitney-Wilcoxon $U$ test, applying Bonferroni correction for multiple comparisons.

Distribution at the population level was determined from filtered positions for each phenological phase through kernel density estimation, using the 'kernelUD' function from the 'adehabitatHR' package in R (Calenge 2011). We used a Lambert Azimuthal Equal Area projection centred in the centroid of all locations and a smoothing parameter equivalent to $186 \mathrm{~km}\left(\sim 2^{\circ}\right.$, depending on latitude), in order to account for the average error in geolocation (Phillips et al. 2004). Kernel density contours of 50 and $95 \%$ were considered to represent, respectively, the core areas of activity and the areas of active use for each period (Pinet et al. 2011a).

\subsection{At-sea activity analysis}

Mk13 and Mk14 geolocator models measure the conductivity in saltwater every $3 \mathrm{~s}$ and summarize the result in 10 min blocks, with values ranging from 0 (the whole block was continuously dry) to 200 (the whole block was continuously wet) (Afanasyev 2004). Mk19 geolocator model provides a different data resolution, storing the time stamp when geolocator recordings change from wet to dry and vice versa; data recorded with Mk19 loggers were transformed to match Mk13 and Mk14 data resolution. Saltwater immersion data can be used as a proxy to infer activity patterns of seabirds, providing insights into behavioural strategies at different temporal scales (e.g. circadian, daily or seasonal; Mackley et al. 2011, Rayner et al. 2012, Cherel et al. 2016). Activity patterns inform whether species are mainly diurnal or nocturnal (both situations have been described in petrels; e.g. Bugoni et al. 2009, Ramos et al. 2015). This may be relevant for species inhabiting oligotrophic oceanic regions, such as gadfly petrels, where diel vertical migration of potential prey can influence seabird behaviour (Dias et al. 2012, Navarro et al. 2013). We explored the activity patterns between day and night throughout the annual cycle based on the time that every logger remained in wet mode. Sunrise and sunset times for each day were derived from geolocator transition files (files with extension 'trn'). We first evaluated daily time spent on the water (in \%) for successful and failed breeders at each phenological phase, and for day and night separately. For visualization purposes only, we modelled daily activity at sea during day and night using generalized additive mixed models (GAMMs), separately for successful and failed breeders. We included Julian date as a smoothing term and bird identity as a random term. The resulting values showed the proportion of day and night spent on the water, accounting for the changes of day length throughout the year. We used the 'mgcv' package in R (Wood \& Augustin 2002), based on penalized regression splines and generalized cross-validation, to select the appropriate smoothing parameters. Moonlight can influence activity patterns of petrels, particularly during the non-breeding period (e.g. Yamamoto et al. 2008, Ramos et al. 2016), so we evaluated the effect of moonlight levels on nocturnal activity during the non-breeding period. We focused on this period to avoid any constraints that breeding might have on activity patterns. We used GAMMs to estimate nocturnal time on water during the nonbreeding period as a response of the number of days since the full moon in November each year (see Ramos et al. 2016 for more details of the approach) as a smoothing term. This allowed us to determine cyclicity in the time spent on water during non-breeding in relation to the lunar cycle. Finally, nocturnal time on water during the non-breeding period was regressed against moonlight levels (from 0 during a new moon, to 100 during a full moon) using locally weighted, non-parametric regressions (Jacoby 2000).

\subsection{Habitat modelling}

We used MaxEnt 3.3.3k software to develop habitat suitability models (Phillips et al. 2006, Elith et al. 2011). Taking into account similar studies (Quillfeldt et al. 2013, Ramírez et al. 2013, Ramos et al. 2015), 7 environmental variables were selected through jackknife test for their possible importance for predicting Atlantic petrel distribution: seafloor depth (BAT, m), bathymetric gradient (BATG, \%; estimated as proportional change of seafloor depth calculated as 100 $\times$ [max. value - min. value] / [max. value]), surface chlorophyll a concentration (CHLA, $\mathrm{mg} \mathrm{m}^{-3}$ as a proxy of biological production), distance to the colony (DCOL, km), sea surface temperature (SST, 
$\left.{ }^{\circ} \mathrm{C}\right)$, salinity (SAL, g salt per $\mathrm{kg}$ water) and wind speed (WIND, $\mathrm{m} \mathrm{s}^{-1}$ ). The environmental information layers were downloaded as monthly averages from the ERDDAP data server in raster format (Simons 2017). In order to select those environmental variables that better explain the distribution of Atlantic petrels, we used the function 'VariableSelection' from 'MaxentVariableSelection' package in R (Jueterbock et al. 2016). We first excluded those variables that contributed less than $5 \%$ to the model (contribution threshold $=0.5$ ) and then excluded the correlated environmental variables (Pearson correlation, correlation threshold $=0.7$ ), keeping those with the highest contribution score. As monthly variables of BAT and BATG were correlated (Table S1), and WIND and SAL explained $<5 \%$ of the distribution for all phenological phases, we reduced environmental predictors to 4 non-redundant variables: BATG, CHLA, DCOL and SST. Environmental layers were averaged for each phenological phase and resampled to a spatial resolution of $2^{\circ}$, in order to match the spatial error in geolocation data. With those layers, habitat suitability models for each phase were generated using 1000 possible random locations from inside $50 \%$ kernel density contours. Each final model was the average of 100 models and their fit was evaluated using the area under the curve (AUC) statistic, which measures the ability of model predictions to discriminate species presence from background locations.

\subsection{Feather sampling and SIA}

We analyzed the stable isotopes of nitrogen $\left(\delta^{15} \mathrm{~N}\right)$ and carbon $\left(\delta^{13} \mathrm{C}\right)$ in the $1^{\text {st }}, 3^{\text {rd }}, 5^{\text {th }}, 7^{\text {th }}$ and $10^{\text {th }}$ primary feathers (P1, P3, P5, P7 and P10), the $13^{\text {th }}$ secondary feather (S13) and the $6^{\text {th }}$ tail feather (rectrix, R6) sampled from 8 dead Atlantic petrels (we could not distinguish if they were immature or adults) found on Gough Island in September 2009. As feathers are metabolically inert once formed, they retain the $\delta^{15} \mathrm{~N}$ and $\delta^{13} \mathrm{C}$ values from the bird's diet at the time of growth, when they are irrigated by blood. Therefore, stable isotopes from feathers provide information about trophic levels $\left(\delta^{15} \mathrm{~N}\right)$ and foraging areas $\left(\delta^{13} \mathrm{C}\right)$ when feathers were growing (Hobson et al. 1994, Cherel et al. 2000). All feathers were cleaned in a $0.50 \mathrm{M} \mathrm{NaOH}$ solution, rinsed twice in distilled water in order to remove any contamination and oven-dried at $60^{\circ} \mathrm{C}$ to constant mass. Thereafter, feathers were flash-frozen with liquid nitrogen and ground using a cryogenic grinder (Spex Certiprep 6850) to obtain a fine powder. Subsamples of
0.30-0.32 mg were weighed and placed into tin capsules to be oxidized in a Flash EA1112 and hightemperature conversion elemental analyzer (TC/EA) coupled to a Delta $\mathrm{C}$ stable isotope mass spectrometer through a Conflo III interface (ThermoFinnigan) in Serveis Científico-Tècnics of the University of Barcelona (Spain). Stable isotope ratios are expressed in $\delta$ conventional notation as parts per thousand $(\%)$ according to the following equation: $\delta X=\left[\left(R_{\text {sample }} /\right.\right.$ $\left.R_{\text {standard }}\right)-1$ ] $\times 1000$, where $X$ is ${ }^{15} \mathrm{~N}$ or ${ }^{13} \mathrm{C}$ and $R$ corresponds to ratio ${ }^{15} \mathrm{~N} /{ }^{14} \mathrm{~N}$ or ${ }^{13} \mathrm{C} /{ }^{12} \mathrm{C}$ related to the standard values. $R_{\text {standard }}$ for ${ }^{15} \mathrm{~N}$ is atmospheric nitrogen (air) and for ${ }^{13} \mathrm{C}$ is Vienna Pee Dee Belemnite (VPDB). The international standards applied (IAEA $\mathrm{N}_{1}$, IAEA $\mathrm{N}_{2}$, USGS 34 and IAEA 600 for $\mathrm{N}_{\text {; IAEA }}$ $\mathrm{CH}_{7}$, IAEA $\mathrm{CH}_{6}$, USGS 40 and IAEA 600 for C) were inserted every 12 feather samples to calibrate the system and compensate for any drift over time. Values of $\delta^{15} \mathrm{~N}$ and $\delta^{13} \mathrm{C}$ were compared to those of other petrels (Procellariidae) that overlap their distribution with the Atlantic petrel's non-breeding range.

\subsection{Ethics statement}

All work was conducted in accordance with the appropriate institutional guidelines (University of Cape Town Animal Ethics Committee: 2014/V10/ PRyan and 2017/V10REV/PRyan), and with the approval of the Tristan da Cunha government. The weight of tagged birds was $>500 \mathrm{~g}$ and the weight of geolocator was $\sim 2 \mathrm{~g}$, which was well below the deleterious recommended threshold of $3-5 \%$ of body weight for back-mounted devices (Phillips et al. 2003, Igual et al. 2005, Passos et al. 2010). All birds were handled in strict accordance with good animal practice; deployment and recovery of geolocators took $<5$ min and had no visible deleterious effects on study animals.

\section{RESULTS}

\subsection{Phenology and spatial distribution}

All tracked birds remained within the South Atlantic Ocean, with most time spent west of the breeding islands. Successful and failed breeders showed similar spatial distributions in each phenological phase (Fig. 2 shows detailed distribution of each phenological group). Adults spent the non-breeding period off northern Argentina, Uruguay and southern Brazil; during the pre-laying exodus, they mainly used the waters 

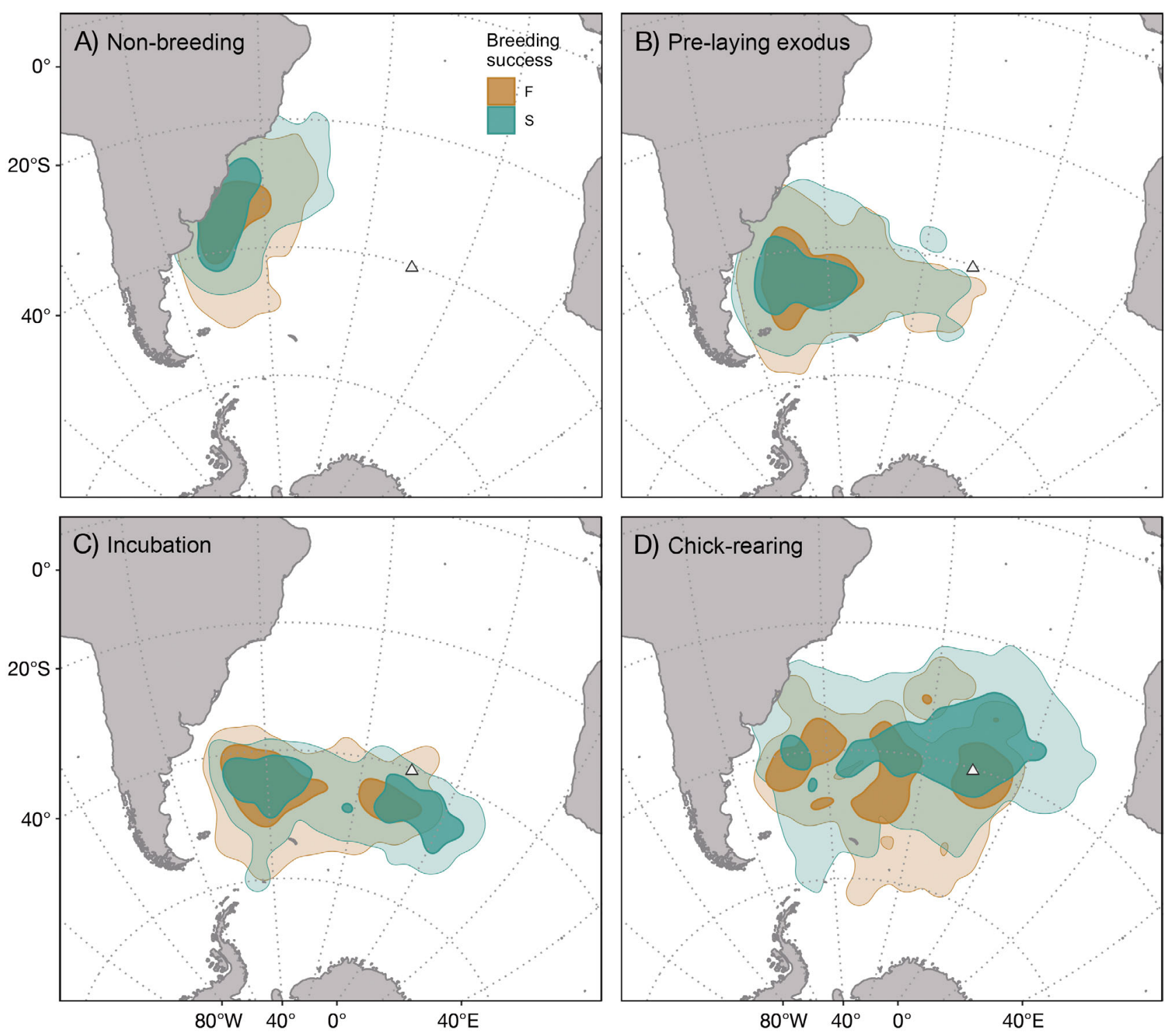

Fig. 2. Year-round distributions of adult Atlantic petrels (successful [S] and failed [F] breeders separately). Filled contours refer to $50 \%$ (darker polygons) and 95\% (lighter polygons) kernel utilization distributions (core areas of activity and the areas of active use, respectively) in the South Atlantic Ocean at each phenological phase. Triangle: breeding colony at Gough Island

over the edge of the South American continental shelf, whereas during incubation and chick-rearing they used 2 main foraging areas, one around Gough Island and another closer to the South American coast (Fig. 2).

Multivariate hierarchical clustering based on phenology identified 2 distinct clusters of birds (Fig. 1). The mean silhouette width, with a value of 0.59 , provided reasonable support for the structure (Fig. S2). Three year-round trips presented low widths $(<0.25)$, which indicated low support for the classification of these samples, but details of their individual phenology support that their classification is more related to failed than to successful breeders (see Figs. S2 \& S3 for a detailed explanation). Previous knowledge of breeding phenology based on observations on land (Cuthbert 2004) suggests that late migrants were successful breeders, whereas early migrants were failed breeders (see Section 4 for an extended explanation). Thus, following the clustering results, we described the phenology of the Atlantic petrels and detailed the breeding schedules separately for successful $(n=10)$ and failed breeders $(n=8$; Table 1$)$. Successful breeders left Gough Island at the end of December and carried out a post-breeding migration towards South America. They arrived at the nonbreeding area off northern Argentina, Uruguay and southern Brazil (Fig. 2A) at the beginning of January and stayed in the area for $98 \mathrm{~d}$. Successful breeders 
Table 1. Phenology of adult Atlantic petrels detailed separately for successful and failed breeders. Starting date corresponds to the mean date (day/month mean $\pm \mathrm{SD}$, over all years of study) when each phenological phase or migration starts. Last column provides results of Mann-Whitney-Wilcoxon $U$ tests between successful and failed breeders' phenological dates, applying Bonferroni correction for multiple comparisons

\begin{tabular}{|c|c|c|c|}
\hline Phenological phase & Successful $(\mathrm{n}=10)$ & Failed $(n=8)$ & Mann-Whitney-Wilcoxon $U$ test \\
\hline \multicolumn{4}{|c|}{ Post-breeding migration } \\
\hline Start date & $25 / 12 \pm 8.1$ & $19 / 09 \pm 32.0$ & $W=80.0 ; \mathrm{p}<0.001$ \\
\hline Duration (d) & $9.6 \pm 3.1$ & $10.7 \pm 3.4$ & $W=0.6 ; \mathrm{p}=0.591$ \\
\hline \multicolumn{4}{|l|}{ Non-breeding } \\
\hline Start date & $04 / 01 \pm 6.1$ & $30 / 09 \pm 31.1$ & $W=80.0 ; \mathrm{p}<0.001$ \\
\hline Duration (d) & $97.7 \pm 4.2$ & $168.0 \pm 29.0$ & $W=0.0 ; \mathrm{p}=0.001$ \\
\hline \multicolumn{4}{|c|}{ Pre-breeding migration } \\
\hline Start date & $11 / 04 \pm 4.7$ & $17 / 03 \pm 10.9$ & $W=70.0 ; \mathrm{p}=0.001$ \\
\hline Duration (d) & $5.3 \pm 3.0$ & $4.1 \pm 2.7$ & $W=0.4 ; \mathrm{p}=0.373$ \\
\hline \multicolumn{4}{|l|}{ Pre-breeding } \\
\hline Start date & $17 / 04 \pm 5.6$ & $21 / 03 \pm 9.1$ & $W=70.0 ; \mathrm{p}=0.001$ \\
\hline Duration (d) & $9.4 \pm 3.8$ & $24.6 \pm 18.2$ & $W=0.1 ; \mathrm{p}=0.106$ \\
\hline \multicolumn{4}{|l|}{ Pre-laying exodus } \\
\hline Start date & $26 / 04 \pm 7.3$ & $15 / 04 \pm 15.1$ & $W=56.5 ; \mathrm{p}=0.039$ \\
\hline Duration (d) & $78.3 \pm 4.2$ & $77.43 \pm 16.8$ & $W=0.5 ; \mathrm{p}=0.461$ \\
\hline \multicolumn{4}{|l|}{ Incubation } \\
\hline Start date & $13 / 07 \pm 5.3$ & $01 / 07 \pm 11.4$ & $W=61.0 ; \mathrm{p}=0.013$ \\
\hline Duration $(d)^{a}$ & $58.0 \pm 7.5$ & $82.0 \pm 0.0$ & \\
\hline \multicolumn{4}{|l|}{ Chick-rearing } \\
\hline Start date & $25 / 08 \pm 8.1$ & $03 / 09 \pm 12.7$ & $W=14.0 ; \mathrm{p}=0.197$ \\
\hline Duration $(\mathrm{d})^{\mathrm{b}}$ & $122.1 \pm 10.1$ & $33.8 \pm 31.4$ & \\
\hline \multicolumn{4}{|c|}{$\begin{array}{l}\text { aDetails about incubation bouts were obtained from } 4 \text { successful breeders and } 1 \text { failed breeder for which incubation period } \\
\text { was not interrupted by deployment or recovery of the logger. This small number of birds prevents us from comparing the } \\
\text { duration of incubation. Because only one individual of a couple was tracked, the actual length of the incubation period } \\
\text { could be longer }\end{array}$} \\
\hline \multicolumn{4}{|c|}{$\begin{array}{l}{ }^{\mathrm{b}} \text { Duration of chick-rearing was not compared due to the small amount of data for failed breeders ( } 3 \text { birds performed post- } \\
\text { breeding migration immediately after incubation) }\end{array}$} \\
\hline
\end{tabular}

started the pre-breeding migration back to the colony in the middle of April, arriving 5 d later. In late April, at the beginning of the breeding season, they travelled to off the northern Argentinean coast and the Falkland Islands for the pre-laying exodus (Fig. 2B), returning in the middle of July to lay and incubate the egg (Fig. 2C). Detailed data about incubation (Table 1) were obtained from 4 successful breeders and 1 failed breeder for which the deployment or recovery of the logger did not interrupt the incubation period. Note, however, that the total length of the incubation period could be longer than recorded from the geolocator data because only one bird of each pair was tracked and its partner could have done the first or last bout. Successful breeders incubated the egg in 2 ( 3 birds) or 3 bouts ( 1 bird), with a median duration $( \pm 95 \%$ confidence interval) of $16.0 \pm 3.6 \mathrm{~d}$ ( $\mathrm{n}=9$ bouts). One failed breeder also incubated in 3 bouts $(16.0 \pm 3.6 \mathrm{~d})$. Chicks hatched in late August-September, when the adults foraged in the same areas used during incubation (one off the
Argentinean continental shelf, and one closer to Gough Island; Fig. 2C,D). Failed breeders left for the non-breeding grounds earlier than successful breeders, had a longer non-breeding period, and returned to the colony earlier the following season (Table 1, Fig. 1B). The apparent result of failed breeders laying earlier but hatching later than successful breeders (Table 1) was not taken in consideration because deploying and recovering of geolocators took place during incubation, thus breaking the connection between incubation and subsequent chick-rearing (i.e. the consideration as successful or failed breeders relate only to the year right after the logger deployment and cannot be maintained to the next year).

\subsection{At-sea activity}

Both successful and failed breeders spent less time on the water during the breeding period (pre-laying exodus, incubation and chick-rearing) than during 
the non-breeding period (Fig. 3, Table S2). Both successful and failed breeders noticeably increased the time on water during the non-breeding period, although in accordance with phenology, failed breeders clearly advanced this pattern in the calendar (Fig. 3). Despite petrels showing similar proportions of time spent on water during day and night within each phenological phase, the proportion of time on water was slightly higher at night than during the day (Fig. 3), except during the non-breeding period, when nocturnal activity was clearly influenced by moonlight (Fig. 4). During this period, tracked birds spent more time on water during nights at new moon and spent more time flying on moonlit nights (Fig. 4).

\subsection{Habitat modelling}

The importance of each environmental variable in the MaxEnt models differed between phenological phases (Table 2, Fig. S4). The most important variables were $\operatorname{SST}\left(20-25^{\circ} \mathrm{C}\right)$ in the non-breeding period; DCOL (2500-4000 km) during the pre-laying exodus; DCOL $(0-2500 \mathrm{~km})$ and SST $\left(0-7^{\circ} \mathrm{C}\right)$ during incubation; and DCOL (0-1900 km) during chickrearing (Fig. S4; response curves are detailed in Fig. S5). Fig. 5 compiles the obtained habitat suitability models considering these environmental variables for each phenological phase. During non-breeding, suitable habitats outside the recorded distribution occurred in the southeast Atlantic, especially in the Benguela Upwelling region.

\subsection{Stable isotope values}

Atlantic petrels presented a narrower range of $\delta^{15} \mathrm{~N}$ (13.1-15.5\%) than $\delta^{13} \mathrm{C}$ values (-19.3 to $-16.1 \%$; Fig. 6, Table 3; see Table S3 for detailed values). Both isotopic ranges were wider in P1-P7, showing higher isotopic variability, than within P10 feathers. Both isotopic signatures and variability of S13 and R6 showed similar values to those of P10. Compared with other petrel species moulting in the BrazilFalklands Confluence, Atlantic petrels show lower values of $\delta^{15} \mathrm{~N}$ and $\delta^{13} \mathrm{C}$ (Table 3).

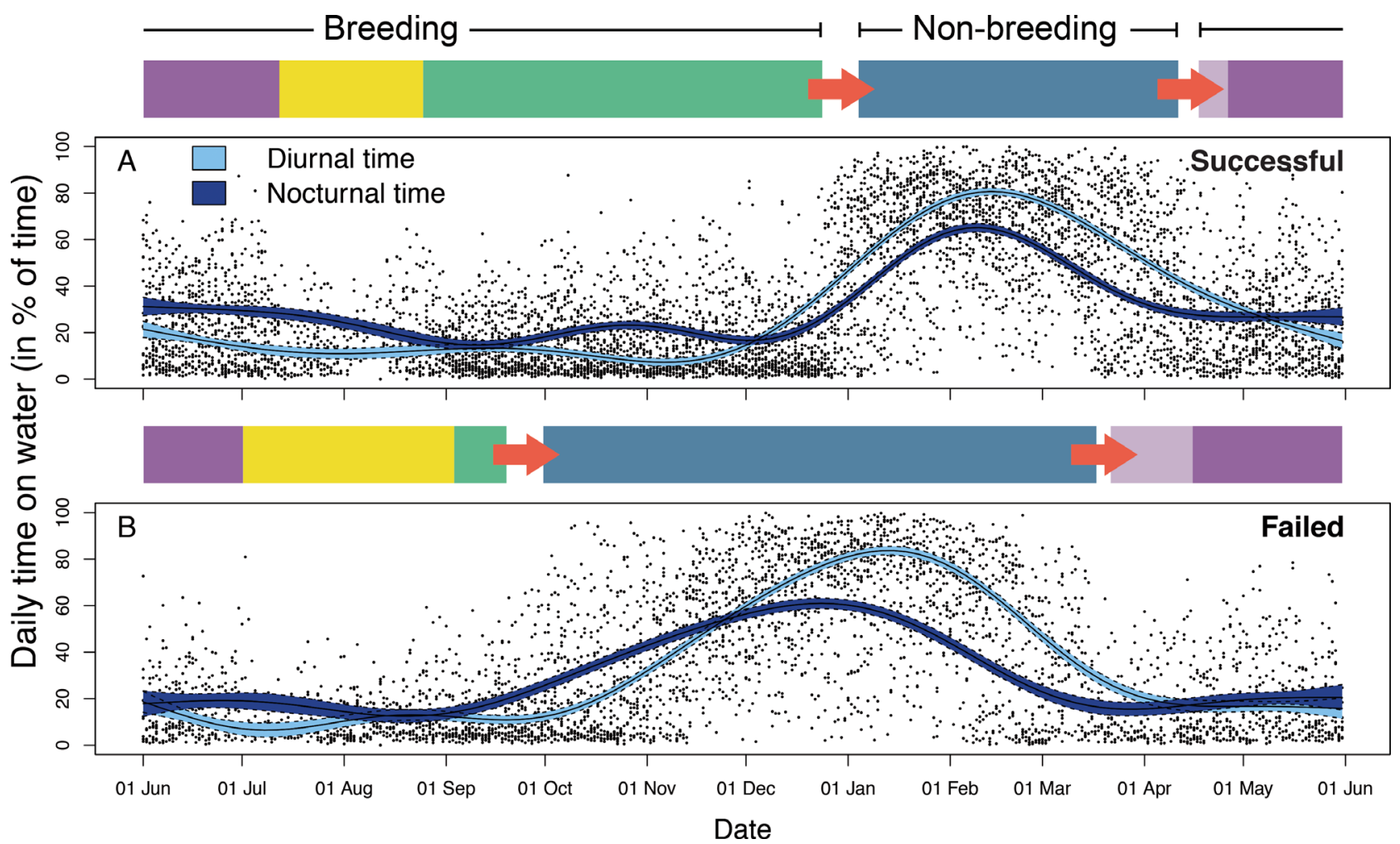

Fig. 3. Year-round at-sea activity patterns of adult Atlantic petrels. Proportion of daily time spent on water (mean $\pm 95 \%$ confidence interval of the slopes; estimated through generalized additive mixed models) during the day and night along the annual cycle. Dots: raw data. Data shown separately for 2 cluster groups: (A) successful and (B) failed breeders. Horizontal bars at the top of each subplot: mean phenological dates of each cluster of birds: pre-laying exodus (dark purple), incubation (yellow), chick-rearing (green), non-breeding (blue) and pre-breeding (time from arrival at breeding grounds to pre-laying exodus; light purple). Arrows: post- and pre-breeding migrations 

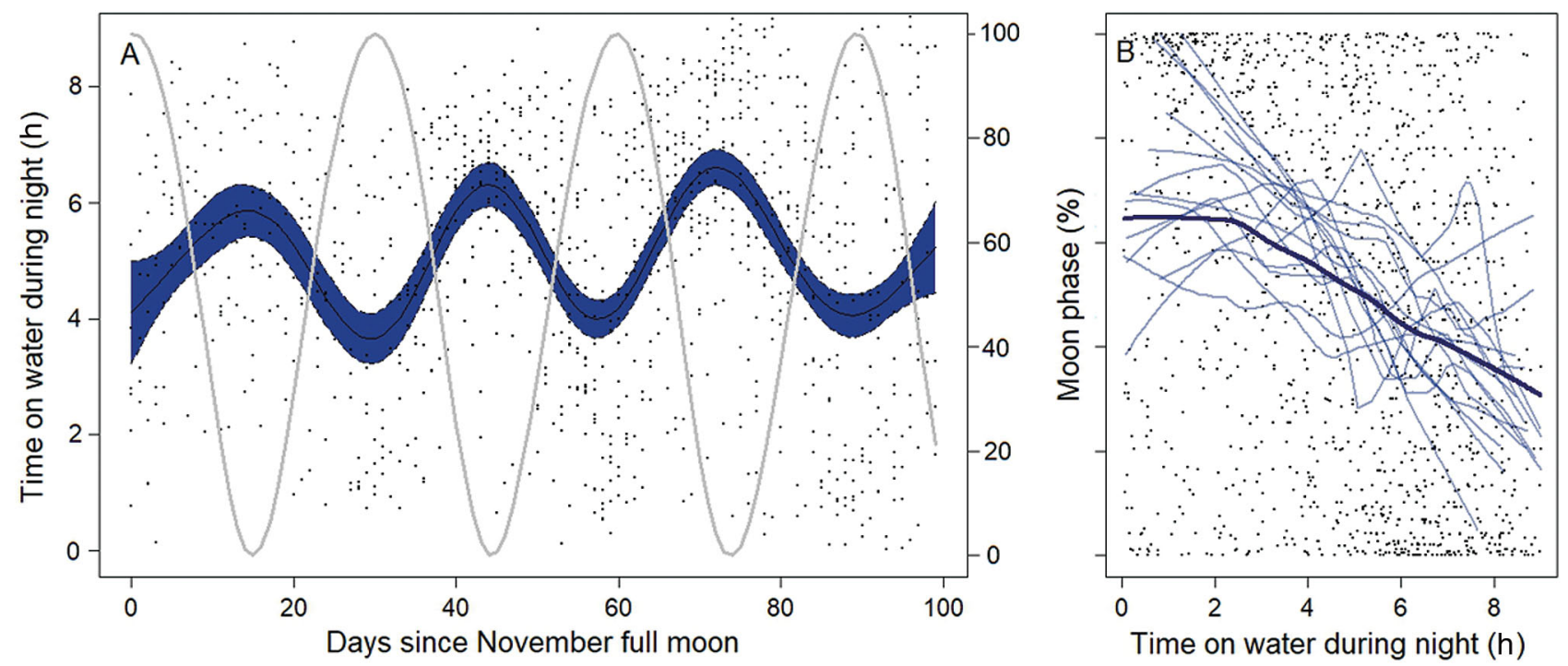

Fig. 4. Effect of moonlight on non-breeding nocturnal activity of Atlantic petrels. (A) Grey line: mean nocturnal time on water estimated through generalized additive mixed models; dark blue shading: $95 \%$ confidence interval of the slopes. To compare non-breeding data of different lunar cycles (2010-2013), daily hours of nocturnal time spent on water were re-scaled to the first full moon of November of each year. Light grey wavy line: moon phase (0: new moon; 100: full moon). (B) Nocturnal time on water during the non-breeding period as function of moonlight. Dots: individual observations; thin lines: individual locally weighted non-parametric regressions; thick line: mean of the species

\section{DISCUSSION}

Our study provides new insights into the spatial ecology of the Atlantic petrel. We report, for the first time, at-sea activity patterns, habitat preferences, moulting strategies and carry-over effects over the entire annual cycle of this Endangered species. Moreover, we extend previous knowledge about the timing of life-cycle events and migration schedules year-round by quantifying phenological variability that arose from presumed breeding success. We present new critical knowledge and refine previous data, providing an ensemble of relevant information for its conservation. However, the small sample size and the lack of immatures in the sample limit the general relevance of our findings.

The breeding phenology inferred in this study generally agrees with data reported in previous colonybased studies (Richardson 1984, Cuthbert 2004, Wanless et al. 2012, Dilley et al. 2015) (Table S4). However, our results highlight considerable withinpopulation variability in phenological events. Multivariate hierarchical clustering based on phenological data allowed us to distinguish between early and late phenological groups. The group with advanced phenology dedicated, on average, about $88 \mathrm{~d}$ less to

Table 2. Most important environmental variables for the probability of occurrence of adult Atlantic petrels. MaxEnt modelling selected gradient of seafloor depth (BATG), chl a concentration (CHLA) as a proxy of biological production, distance to the colony (DCOL) and sea surface temperature (SST) as the most important environmental variables to predict the occurrence of adult Atlantic petrels within $50 \%$ kernel utilization distribution for each phenological phase. Estimates of model fit (as the area under the receiver operating characteristic curve; AUC) and relative importance (as percent contribution, values over $15 \%$ in bold) of these environmental variables. Redundant environmental variables (BAT) and those variables explaining $<5 \%$ of the distribution (SAL and WIND) were excluded during modelling to reduce noise in the outputs. NA: not applicable (i.e. when relative importance or percent contribution $<5 \%$ )

\begin{tabular}{|c|c|c|c|c|c|c|c|c|c|}
\hline & \multirow{2}{*}{ AUC } & \multicolumn{4}{|c|}{ Relative importance (\%) } & \multirow{2}{*}{$\overline{\text { BATG }}$} & \multicolumn{2}{|c|}{-\% Contribution - } & \multirow[b]{2}{*}{ SST } \\
\hline & & BATG & CHLA & DCOL & SST & & CHLA & DCOL & \\
\hline Non-breeding & $0.915 \pm 0.025$ & NA & 11.9 & NA & 83.6 & 22.3 & 11.0 & NA & 66.6 \\
\hline Pre-laying exodus & $0.988 \pm 0.002$ & NA & NA & 94.0 & NA & NA & 28.7 & 59.5 & 11.8 \\
\hline Incubation & $0.991 \pm 0.002$ & NA & NA & 66.5 & 29.9 & NA & NA & 54.4 & 28.7 \\
\hline Chick-rearing & $0.992 \pm 0.002$ & NA & NA & 98.1 & NA & NA & NA & 90.7 & 9.3 \\
\hline
\end{tabular}





Fig. 5. Habitat suitability of Atlantic petrels for every phenological phase derived from environmental modelling. Suitability ranges from light yellow (less suitable habitat) to dark blue (most suitable habitat). Black contour lines: $50 \%$ kernel utilization distribution of positions for both successful and failed breeders; triangle: colony location
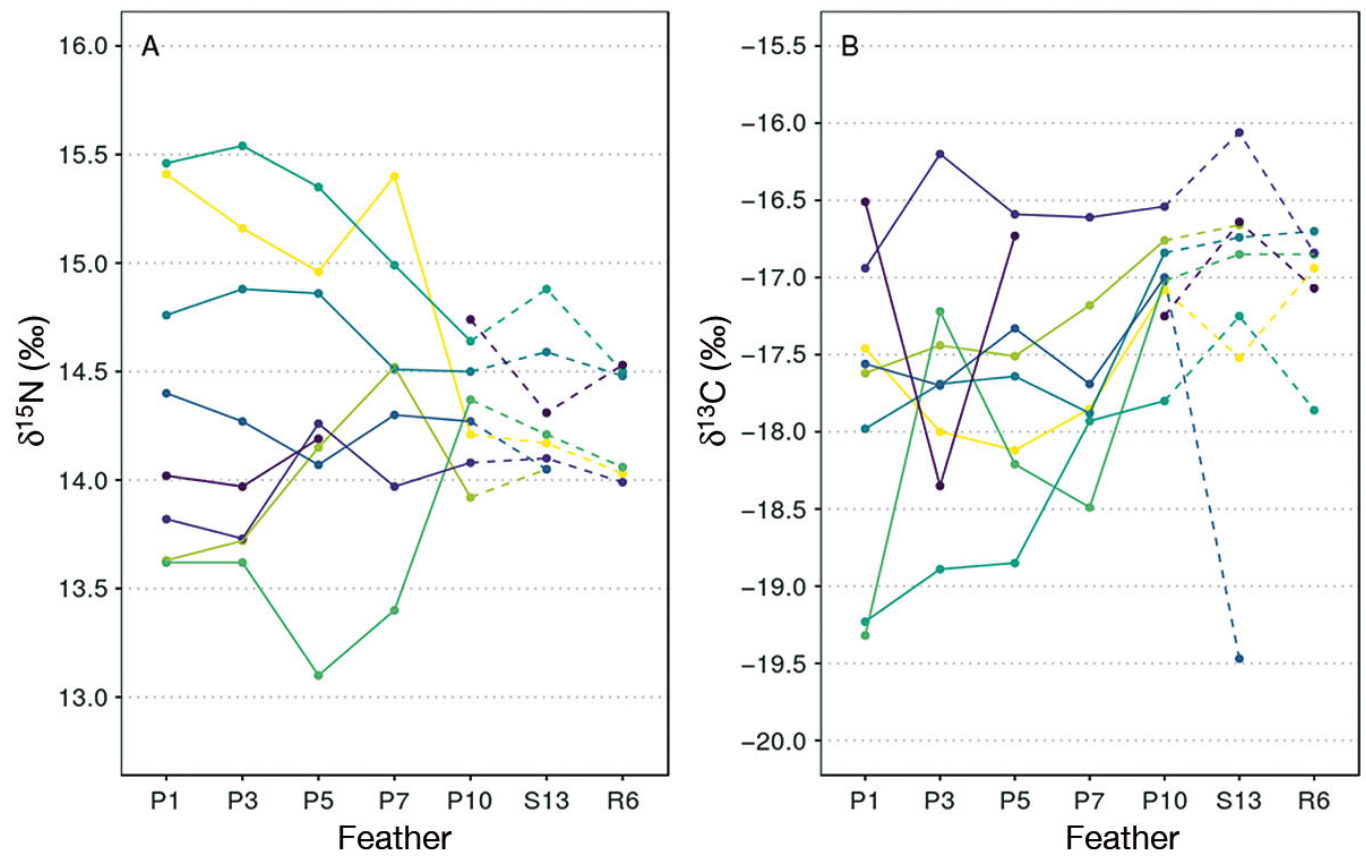

Fig. 6. (A) $\delta^{15} \mathrm{~N}$ and (B) $\delta^{13} \mathrm{C}$ of $1^{\text {st }}, 3^{\text {rd }}, 5^{\text {th }}, 7^{\text {th }}$ and $10^{\text {th }}$ primary feathers (P1, P3, P5, P7 and P10), $13^{\text {th }}$ secondary (S13) and $6^{\text {th }}$ rectrix (R6) feathers of Atlantic petrels $(\mathrm{n}=8$; values in Table 3). Lines connect values corresponding to feathers from the same individual, note that not all sequences are complete. Primary feather replacement is assumed to be simple and descendent in procellariiformes, starting from P1-3 and moulting sequentially towards P10. Secondary and rectrix feathers (here S13 and R6) are thought to be moulted out of the breeding season, not sequentially, as represented by dashed lines (Bridge 2006, Ramos et al. 2009) 
Table 3. Mean $( \pm \mathrm{SD}) \delta^{15} \mathrm{~N}$ and $\delta^{13} \mathrm{C}$ values of feathers from several petrel and shearwater species found in the southern Atlantic Ocean, including $1^{\text {st }}, 3^{\text {rd }}, 5^{\text {th }}, 7^{\text {th }}$ and $10^{\text {th }}$ primary feathers (P1, P3, P5, P7 and P10), 13 ${ }^{\text {th }}$ secondary (S13) and $6^{\text {th }}$ rectrix (R6) feathers of Atlantic petrels breeding on Gough Island. Feathers of great shearwater Ardenna gravis, Manx shearwater Puffinus puffinus, Cory's shearwater Calonectris borealis and white-chinned petrel Procellaria aequinoctialis are known to be moulted in the Brazil-Falklands Confluence

\begin{tabular}{|c|c|c|c|c|c|}
\hline Species & Feather & No. of feathers & $\delta^{15} \mathrm{~N}(\%)$ & $\delta^{13} \mathrm{C}(\%)$ & Source \\
\hline Atlantic petrel & $\begin{array}{l}\text { P1 } \\
\text { P3 } \\
\text { P5 } \\
\text { P7 } \\
\text { P10 } \\
\text { S13 } \\
\text { R6 }\end{array}$ & $\begin{array}{l}8 \\
8 \\
8 \\
7 \\
8 \\
7^{\mathrm{a}} \\
6\end{array}$ & $\begin{array}{l}14.4 \pm 0.7 \\
14.4 \pm 0.7 \\
14.4 \pm 0.7 \\
14.4 \pm 0.6 \\
14.3 \pm 0.3 \\
14.3 \pm 0.3 \\
14.3 \pm 0.3\end{array}$ & $\begin{array}{l}-17.8 \pm 1.0 \\
-17.7 \pm 0.8 \\
-17.6 \pm 0.8 \\
-17.7 \pm 0.6 \\
-17.0 \pm 0.4 \\
-17.4 \pm 0.5 \\
-17.0 \pm 0.4\end{array}$ & Present study \\
\hline Great shearwater & $\mathrm{P} 1$ & 6 & $15.6 \pm 1.2$ & $-16.7 \pm 1.6$ & T. Militão unpubl. data \\
\hline Manx shearwater & R6 & 13 & $17.6 \pm 1.9$ & $-16.3 \pm 0.5$ & T. Militão unpubl. data \\
\hline Cory's shearwater & $\mathrm{S} 13$ & 4 & $13.9 \pm 0.8$ & $-16.4 \pm 0.3$ & T. Militão unpubl. data \\
\hline White-chinned petrel & Body feathers & $8-10$ & $17.6 \pm 1.4$ & $-15.5 \pm 0.8$ & Phillips et al. (2009) \\
\hline
\end{tabular}

chick-rearing (Table 1), probably as a result of breeding failure. In recent years, a high proportion of chicks have been killed by introduced house mice at Gough Island (Dilley et al. 2015). Thus, although breeding outcome was not monitored, the phenological variability found between groups likely is due to breeding success or failure. Both phenological groups differed in the starting date of post-breeding migration and the 5 subsequent phenological phases (Fig. 1, Table 1). The 'early migrants' departed the breeding area between 7 August and 9 November (well before December, when chicks usually fledge; Cuthbert 2004), indicating that birds showing this early post-breeding migration were likely failed breeders. The 'late migrants' started their post-breeding migration in December or later, and therefore, presumably, were successful breeders.

Interestingly, we found that breeding success influenced subsequent phenological phases of the species. Failed breeders not only departed to the non-breeding area earlier and stayed there longer than successful breeders, they also returned earlier to the colony at the onset of the next breeding period. These results demonstrate a carry-over effect on this species not only from the breeding to the non-breeding period, but also to the subsequent breeding period. It is likely that birds without breeding responsibilities that migrate earlier to the non-breeding grounds were able to moult and recover their body condition earlier than successful breeders, potentially improving their chances of breeding successfully in the subsequent breeding attempt (Kokko 1999). Nevertheless, despite the phenological differences between successful and failed breeders, all birds showed similar flyways and non-breeding areas, probably because of the relatively restricted and consistent non-breeding area for the entire species. This last result was also found in Cory's shearwater Calonectris borealis, although their breeding success did not change their migratory schedule (Ramos et al. 2018). However, our findings contrast with previous studies also with Cory's shearwaters and black-legged kittiwakes Rissa tridactyla, where winter distribution depends on reproductive performance (Bogdanova et al. 2011, Catry et al. 2013). Among northern gannets Morus bassanus, foraging grounds also differed between failed and successful breeders (Votier et al. 2017). However, we are aware of the limitations of our sample size, and the need for an experimental design monitoring the breeding performance of every individual in order to be more conclusive on such carry-over effects (e.g. Harrison et al. 2011).

Our geolocation data confirmed that the Southwest Atlantic Ocean is the main distribution range for Atlantic petrels year-round (Ramos et al. 2017). The observed core range is more restricted to the west than traditionally considered (i.e. from east coast of South America to west coast of South Africa), but this might be a consequence of our modest sample size, and the fact that only unsexed adults were tracked in this study (Enticott 1991, Orgeira et al. 2013, Carboneras et al. 2017a). Adults were largely confined to oceanic waters of the central and western South Atlantic. The edge of the South American continental shelf, off northern Argentina, Uruguay and southern Brazil, was exploited during all phenological phases, 
although extension and location of core areas differed between periods (Fig. 2). In this region, the Brazil-Falklands Confluence, where warm waters from the Brazil Current mix with cold waters from the Falklands Current, creates a productive ecosystem that supports a complex community of top predators, including many seabird species (Croxall \& Wood 2002, Olmos 2002, Acha et al. 2004). Although this abundance of top predators results in local competition, the high productivity likely explains why Atlantic petrels exploit this area. Avoidance of competition near Gough Island (where waters are less productive) and the richer waters along the South American continental shelf may explain why birds commute around $3500 \mathrm{~km}$ to a more distant and productive area far from the colony.

The proportion of time spent on water (both during day and night) was lower while breeding than during the non-breeding period (Fig. 3). This pattern is likely explained by moulting phenology. Although there is scant information on the timing of moult in Atlantic petrels, most petrels complete an annual moult of their primary feathers starting immediately after the breeding season in order to avoid overlapping these metabolically demanding periods (breeding and moulting) (Bridge 2006). Moult typically commences with 2-4 inner primaries, but only 1-2 outer primaries are moulted at a time, because their moult has a greater impact on flight performance (Bugoni et al. 2015). The intense replacement of wing feathers during the non-breeding period (see below) decreases flight capability, forcing birds to spend more time on water (Cherel et al. 2016). The effect of moult on flight time was also observed in failed breeders that advanced both the post-breeding migration and the non-breeding period, and thus likely their moulting period (Fig. 3). Another possible contributing factor could be the move from central-place foraging while breeding (i.e. high energy investment to meet the breeding demands) to a lower energy demand during the non-breeding period (Mackley et al. 2011, Cherel et al. 2016). To ensure breeding success, seabirds need to increase foraging effort (Lescroël et al. 2010), which likely means performing both nocturnal and diurnal foraging to provision the chicks either more frequently or with a larger variety of prey. However, during non-breeding period compared to the breeding period, birds spent more time in flight at night (at least during periods of increased moonlight), when some species of cephalopods become more accessible near the surface due to their diel vertical migrations (DVM) (Imber 1973). As reported for other Pterodroma petrel species, cephalo- pods are the main prey of Atlantic petrels, which may include dead or moribund squid floating at the surface during the day (Richardson 1984, Croxall \& Prince 1994, Klages \& Cooper 1997, Perez et al. 2019). Nocturnal activity was clearly influenced by moonlight over the non-breeding period, i.e. petrels spent more time flying with increasing levels of moonlight intensity (Fig. 4). Previous studies have found similar results in other gadfly petrel species and suggest that light intensity during full moon nights could facilitate foraging (e.g. Pinet et al. 2011b, Ramírez et al. 2013, Ramos et al. 2016). However, greater activity levels on well-lit nights may result from DVM organisms remaining in deeper waters when moonlight is brighter, forcing Atlantic petrels to increase their search effort for prey (Benoit-Bird et al. 2009).

We observed high individual variability in isotopic results on several primary feathers obtained from dead specimens (i.e. P1-P7 feathers; Fig. 6, Table 3). This likely indicates that these feathers grew in different individual non-breeding grounds within the general non-breeding area (see Cherel et al. 2000, McMahon et al. 2013). By comparison, the low isotopic variability in P10, S13 and R6 among individuals possibly indicates that these feathers were replaced in a common area for all birds, i.e. around the colony site after arrival from the non-breeding area between end of March and mid-April (Fig. 2). Elliott (1957) reported that birds arriving at Tristan da Cunha at the end of March were still in moult, as were birds carried inland in Brazil by Hurricane Catarina in March 2004 (Bugoni et al. 2007). Although we could not distinguish if the 8 dead specimens found at Gough Island were immature or adults, these results indicate similar phenological patterns in their migratory behaviour to those obtained through geolocator data. The isotopic gradient observed along P1-P7 feathers could reflect a north-south gradient in isotopic baselines, with feathers with lower isotopic values moulted farther north, and those with higher isotopic values moulted further south, in the BrazilFalklands Confluence (Figs. 2A \& 6). This north-south trend is consistent with prey isotopic data (see $\delta^{15} \mathrm{~N}$ in Table 4). However, the lack of a detailed zooplankton isoscapes for the non-breeding distribution prevented us from confirming this gradient at lower trophic levels (McMahon et al. 2013).

It is clear that the edge of the South American continental shelf is an important foraging area for Atlantic petrels year-round. Shelf slopes are important habitats for many squid species, which are caught by fishing fleets year-round along the outer shelf and 
Table 4. Mean $( \pm \mathrm{SD}) \delta^{15} \mathrm{~N}$ and $\delta^{13} \mathrm{C}$ values of several cephalopod species (mantle muscle) from the Brazil Current and BrazilFalklands Confluence

\begin{tabular}{|llcccc|}
\hline Area & Prey & $\begin{array}{c}\text { No. of } \\
\text { samples }\end{array}$ & $\delta^{15} \mathrm{~N}(\%)$ & $\delta^{13} \mathrm{C}(\%)$ & Source \\
\hline Brazil Current & $\begin{array}{l}\text { Doryteuthis (Loligo) pealeii } \\
\text { Illex argentinus }\end{array}$ & 5 & $11.3 \pm 0.5$ & $-17.6 \pm 0.2$ & $\begin{array}{l}\text { Drago et al. (2015) } \\
\text { Drago et al. (2015) }\end{array}$ \\
& $\begin{array}{l}\text { Loligo sanpaulensis } \\
\text { Ommastrephes bartrami/I. argentinus }\end{array}$ & 8 & $9.3 \pm 0.8$ & $-16.7 \pm 0.4$ & Drago et al. (2015) \\
& All species & & $11.4 \pm 0.5$ & $-17.2 \pm 0.2$ & \\
Brazil-Falkland et al. (2010) \\
Confluence & I. argentinus & 5 & $14.7 \pm 0.5$ & $-17.5 \pm 0.4$ & Drago et al. (2015) \\
& I. argentinus & 5 & $15.0 \pm 0.5$ & $-18.1 \pm 0.2$ & \\
& L. sanpaulensis & 2 & $13.9 \pm 0.7$ & $-18.7 \pm 0.2$ & Franco-Trecu et al. (2012) \\
& L. sanpaulensis & 5 & $18.6 \pm 0.2$ & $-16.7 \pm 0.2$ & Drago et al. (2015) \\
& All species & 2 & $13.7 \pm 0.2$ & $-17.9 \pm 0.1$ & Franco-Trecu et al. (2012) \\
& & & $15.2 \pm 0.4$ & $-17.7 \pm 0.2$ & \\
\hline
\end{tabular}

upper slope off southern Brazil (Haimovici et al. 1998, Arkhipkin et al. 2015). However, we did not find an increase in isotopic values with increasing trophic levels when comparing results from flight feathers moulted in the Brazil-Falklands Confluence with those from cephalopod species sampled in the same area (e.g. Drago et al. 2015; see Table 4). This mismatch may arise from differential timing of sampling (i.e. different years and/or seasons within the same year) and from unspecified limitations of using literature isotopic data. Nevertheless, comparisons of $\delta^{15} \mathrm{~N}$ and $\delta^{13} \mathrm{C}$ values of Atlantic petrel feathers with other shearwater species moulting in the Brazil-Falklands Confluence (e.g. great shearwater and white-chinned petrel; Table 3) suggest a lower trophic level of the Atlantic petrel, which might reflect the limited use of fisheries discards by this species, and thus, its lower risk of bycatch compared with other species (Barrett et al. 2007, Bugoni et al. 2008, 2010, Phillips et al. 2009).

Regarding the Atlantic petrel distribution, oceanic productivity may not be a good predictor of its distribution because the species relies on relatively oligotrophic waters for feeding year-round, being a truly oceanic species like most gadfly petrels (Ramos et al. 2016 , 2017). In general, year-round habitat suitability models based on several environmental predictors agree well with the observed species distribution (Fig. 5; Enticott 1991, Orgeira 2001, Carboneras et al. 2017a). However, during the non-breeding period, only 1 of the 2 suitable habitats - the shelf and slopes of the Brazil-Falklands Confluence - fit well with the core range of Atlantic petrels (Fig. 5A). It is not known why Atlantic petrels are so rare in the Benguela Current region (Enticott 1991). Their distribution contrasts markedly with several other seabird species that use both areas during the non-breeding period, such as Scopoli's Calonectris diomedea and Cory's shearwaters (González-Solís et al. 2007). During the pre-laying exodus, 2 suitable habitats were identified, one in northern Argentina and Falkland Islands, and another south of Africa (Fig. 5B), which again was not used by any tracked birds, and is an area with few observations at sea (Enticott 1991). During incubation and chick-rearing, an apparently suitable area in the southeastern Atlantic also was not highly used by tracked birds (Fig. 5C,D), but they do occur in reasonable numbers south of Africa (38$42^{\circ} \mathrm{S}$ ) in November, towards the end of the chickrearing period (P. G. Ryan pers. obs.). Apart from the small sample size, one possible explanation for these differences could be the competitive exclusion or the 'ghost of past' competition with other gadfly petrels in the region (Connell 1980). The great-winged petrel Pterodroma macroptera, which has a similar phenology and diet, is abundant off southern Africa and largely absent from the southwest Atlantic (Ridoux 1994, Brooke 2004, BirdLife International 2017a, Carboneras et al. 2017b). It breeds abundantly at islands in the Southwest Indian Ocean, and used to be common at Tristan and Gough, but has become rare in recent years due to hunting (at Tris$\tan$ ) and introduced predators (at both islands) (BirdLife International 2017a, Ramos et al. 2017). The smaller soft-plumaged petrel Pterodroma mollis remains abundant at Gough and the uninhabited Tristan islands, as well as at islands in the southwest Indian Ocean, and is the most common gadfly petrel in the southeast Atlantic, but performs the opposite phenology to the Atlantic petrel (BirdLife International $2017 \mathrm{a}$, Ramos et al. 2017). In addition, the distribution and abundance of squids is poorly known in austral oceans, but commercial squid fisheries are more abundant along the South American shelf and 
shelf slopes than off South Africa (FAO 2005). This fact could indicate a higher abundance of the main prey for gadfly petrels off South America, where Atlantic petrels overlap with other gadfly petrels, such as the Desertas petrel Pterodroma deserta (BirdLife International 2017a, Ramos et al. 2017). This area is important for fishing fleets, and the high fishing intensity may decrease prey abundance for Atlantic petrels and other seabirds (Furness 2003, Bugoni et al. 2008). It also supports large numbers of vessels with their inherent potential threats (mortality, but also sub-lethal effects) to seabirds and marine life (Finkelstein et al. 2006, Lewison et al. 2012, Krüger et al. 2017, Rodríguez et al. 2017). Since this is the area where all tracked birds spent their nonbreeding period, and because Gough Island is virtually the only breeding location for this species, a good conservation strategy for both areas is essential to ensure sustainability of the Atlantic petrel. Indeed, one Ecologically or Biologically Significant Area (EBSA) and several Important Bird Areas (IBAs) overlap with the species' non-breeding distribution. For the breeding location, one Marine Protected Area (MPA) is designated and several IBAs and MPAs are proposed around Tristan da Cunha Island and Gough Island (which is part of an UNESCO World Heritage Site and also a Wetlands of International Importance under the Ramsar Convention), which should help to conserve the species (BirdLife International 2017c, Convention on Biological Diversity 2017, Dias et al. 2017, Marine Conservation Institute 2017, UNESCO 2019).

\section{CONCLUSIONS}

In this study, we described important aspects of the spatio-temporal ecology of Atlantic petrels. The nonbreeding period of successful breeders lasted from the end of December to mid-April. Habitat preferences highlighted the South American continental shelf as an extremely important area for the species. We related activity patterns with breeding constraints, foraging behaviour and, together with SIA, provided new insights into the timing of wing moult. We also provided evidence of carry-over effects between consecutive breeding attempts. However, further studies tracking larger numbers of birds of different sexes and ages and monitoring their breeding performance at the colony would provide more reliable understanding of ecological factors that determine the at-sea distribution and behaviour of this Endangered seabird.
Acknowledgements. The Ministerio de Educación y Ciencia and Ministerio de Ciencia e Innovación from the Spanish Government (Projects CGL2006- 01315/BOS, CGL201342585-P, CGL2009-11278/BOS) financially supported this study. Logistical support and financial funding during field work was provided by the South African Department of Environmental Affairs and the National Research Foundation, through the South African National Antarctic Programme, with additional support from the Royal Society for the Protection of Birds. R.R., Z.Z. and J.M.R.G. were supported by Spanish MINECO (Juan de la Cierva postdoctoral programme, JCI-2012-11848), Universitat de Barcelona (UB, APIF/2012) and Spanish MECD (FPU, AP2009-2163), respectively. Permission to conduct research at Gough Island was granted by the Administrator and Island Council of Tristan da Cunha, through Tristan's Conservation Department. We thank R. Ronconi for his help during field work, and the many field assistants who deployed and recovered tags at Gough Island. We thank 3 anonymous referees for their comments to improve an earlier version of the manuscript.

\section{LITERATURE CITED}

Acha EM, Mianzan HW, Guerrero RA, Favero M, Bava J (2004) Marine fronts at the continental shelves of austral South America: physical and ecological processes. J Mar Syst 44:83-105

Afanasyev V (2004) A miniature daylight level and activity data recorder for tracking animals over long periods. Mem Natl Inst Polar Res 58:227-233

Arkhipkin AI, Rodhouse PGK, Pierce GJ, Sauer W and others (2015) World squid fisheries. Rev Fish Sci Aquacult 23:92-252

Barrett RT, Camphuysen KCJ, Anker-Nilssen T, Chardine JW and others (2007) Diet studies of seabirds: a review and recommendations. J Mar Sci 64:1675-1691

* Benoit-Bird JK, Au WW, Wisdom DW (2009) Nocturnal light and lunar cycle effects on diel migration of micronekton. Limnol Oceanogr 54:1789-1800

BirdLife International (2017a) IUCN Red List for birds. www. birdlife.org (accessed 9 Sep 2017)

*BirdLife International (2017b) Seabird tracking database: tracking ocean wanderers. http://seabirdtracking.org/ mapper/?dataset_id=966 (accessed 21 Oct 2018)

BirdLife International (2017c) Marine IBA e-atlas: delivering site networks for seabird conservation. https://maps.bird life.org/marineIBAs/default.html (accessed 4 Jun 2017)

Bogdanova MI, Daunt F, Newell M, Phillips RA, Harris MP, Wanless S (2011) Seasonal interactions in the blacklegged kittiwake, Rissa tridactyla: links between breeding performance and winter distribution. Proc R Soc B 278:2412-2418

Bridge ES (2006) Influences of morphology and behavior on wing-molt strategies in seabirds. Mar Ornithol 34:7-19

Bried J, Pontier D, Jouventin P (2003) Mate fidelity in monogamous birds: a re-examination of the Procellariiformes. Anim Behav 65:235-246

Brooke M (2004) Albatrosses and petrels across the world. Oxford University Press, Oxford

Bugoni L, Sander M, Costa ES (2007) Effects of the first southern Atlantic hurricane on Atlantic petrels (Pterodroma incerta). Wilson J Ornithol 119:725-729

*Bugoni L, Mancini PL, Monteiro DS, Nascimento L, Neves TS (2008) Seabird bycatch in the Brazilian pelagic long- 
line fishery and a review of capture rates in the southwestern Atlantic Ocean. Endang Species Res 5: 137-147

* Bugoni L, D'Alba L, Furness R (2009) Marine habitat use of wintering spectacled petrels Procellaria conspicillata, and overlap with longline fishery. Mar Ecol Prog Ser 374: 273-285

Bugoni L, McGill RAR, Furness RW (2010) The importance of pelagic longline fishery discards for a seabird community determined through stable isotope analysis. J Exp Mar Biol Ecol 391:190-200

* Bugoni L, Naves LC, Furness RW (2015) Moult of three Tristan da Cunha seabird species sampled at sea. Antarct Sci $27: 240-251$

Calenge C (2011) Home range estimation in R: the adehabitatHR package. http://cran.r-project.org/web/packages/ adehabitatHR/vignettes/adehabitatHR.pdf

* Caravaggi A, Cuthbert RJ, Ryan PG, Cooper J, Bond AL (2019) The impacts of introduced house mice on the breeding success of nesting seabirds on Gough Island. Ibis 161:648-661

* Carboneras C, Jutglar F, Kirwan GM (2017a) Atlantic petrel (Pterodroma incerta). In: del Hoyo J, Elliott A, Sargatal J, Christie DA, de Juana E (eds) Handbook of the birds of the world alive. Lynx Edicions, Barcelona. https://www. hbw.com/node/52525 (accessed 24 Nov 2017)

* Carboneras C, Jutglar F, Kirwan GM (2017b) Great-winged petrel (Pterodroma macroptera). In: del Hoyo J, Elliott A, Sargatal J, Christie DA, de Juana E (eds) Handbook of the birds of the world alive. Lynx Edicions, Barcelona. www.hbw.com/node/52519 (accessed 23 Dec 2017)

* Catry P, Dias MP, Phillips RA, Granadeiro JP (2013) Carryover effects from breeding modulate the annual cycle of a long-distance migrant: an experimental demonstration. Ecology 94:1230-1235

* Cherel Y, Hobson KA, Weimerskirch H (2000) Using stableisotope analysis of feathers to distinguish moulting and breeding origins of seabirds. Oecologia 122:155-162

Cherel Y, Quillfeldt P, Delord K, Weimerskirch H (2016) Combination of at-sea activity, geolocation and feather stable isotopes documents where and when seabirds molt. Front Ecol Evol 4:3

Clay TA, Phillips RA, Manica A, Jackson HA, Brooke MDL (2017) Escaping the oligotrophic gyre? The year-round movements, foraging behaviour and habitat preferences of Murphy's petrels. Mar Ecol Prog Ser 579:139-155

* Connell J (1980) Diversity and the coevolution of competitors, or the ghost of competition past. Oikos 35:131-138

Convention on Biological Diversity (2017) Ecologically or biologically significant areas (EBSAs), southern Brazilian sea. https://chm.cbd.int/database/record?documentID= 200107 (accessed 4 Jun 2017)

* Croxall JP, Prince PA (1994) Dead or alive, night or day: How do albatrosses catch squid? Antarct Sci 6:155-162

* Croxall JP, Wood AG (2002) The importance of the Patagonian Shelf for top predator species breeding at South Georgia. Aquat Conserv 12:101-118

Croxall JP, Butchart SHM, Lascelles B, Stattersfield AJ, Sullivan B, Symes A, Taylor P (2012) Seabird conservation status, threats and priority actions: a global assessment. Bird Conserv Int 22:1-34

Cuthbert RJ (2004) Breeding biology of the Atlantic petrel, Pterodroma incerta, and a population estimate of this and other burrowing petrels on Gough Island, South Atlantic Ocean. Emu 104:221-228
Cuthbert RJ, Louw H, Lurling J, Parker G and others (2013) Low burrow occupancy and breeding success of burrowing petrels at Gough Island: a consequence of mouse predation. Bird Conserv Int 23:113-124

* Dias M, Granadeiro J, Catry P (2012) Working the day or the night shift? Foraging schedules of Cory's shearwaters vary according to marine habitat. Mar Ecol Prog Ser 467: 245-252

Dias MP, Oppel S, Bond AL, Carneiro APB and others (2017) Using globally threatened pelagic birds to identify priority sites for marine conservation in the South Atlantic Ocean. Biol Conserv 211:76-84

* Dilley B, Davies D, Bond AL, Ryan PG (2015) Effects of mouse predation on burrowing petrel chicks at Gough Island. Antarct Sci 27:543-553

* Drago M, Franco-Trecu V, Zenteno L, Szteren D and others (2015) Sexual foraging segregation in South American sea lions increases during the pre-breeding period in the Río de la Plata plume. Mar Ecol Prog Ser 525:261-272

* Elith J, Phillips SJ, Hastie T, Dudík M, Chee YE, Yates CJ (2011) A statistical explanation of MaxEnt for ecologists. Divers Distrib 17:43-57

* Elliott HFI (1957) A contribution to the ornithology of the Tristan da Cunha Group. Ibis 99:545-586

Enticott JW (1991) Distribution of the Atlantic petrel Pterodroma incerta at sea. Mar Ornithol 19:49-60

FAO (2005) Review of the state of world marine fishery resources. FAO Fish Tech Pap No. 457. FAO, Rome

Finkelstein M, Keitt BS, Croll DA, Tershy B and others (2006) Albatross species demonstrate regional differences in North Pacific marine contamination. Ecol Appl 16: 678-686

Flood B, Fisher A (2013) Multimedia identification guide to North Atlantic seabirds: Pterodroma petrels. Scilly Pelagics, Essex

F Franco-Trecu V, Aurioles-Gamboa D, Arim M, Lima M (2012) Prepartum and postpartum trophic segregation between sympatrically breeding female Arctocephalus australis and Otaria flavescens. J Mammal 93:514-521

Furness R (2003) Impacts of fisheries on seabird communities. Sci Mar 67:33-45

* González-Solís J, Shaffer SA (2009) Introduction and synthesis: spatial ecology of seabirds at sea. Mar Ecol Prog Ser 391:117-120

* González-Solís J, Croxall JP, Oro D, Ruiz X (2007) Transequatorial migration and mixing in the wintering areas of a pelagic seabird. Front Ecol Environ 5:297-301

*Gémillet D, Boulinier T (2009) Spatial ecology and conservation of seabirds facing global climate change: a review. Mar Ecol Prog Ser 391:121-137

Haimovici M, Brunetti NE, Rodhouse PG, Csirke J, Leta RH (1998) Illex argentinus. In: Rodhouse PG, Dawe EG, O'Dor RK (eds) Squid recruitment dynamics. The genus Illex as a model, the commercial Illex species and influences on variability. FAO Fish Tech Pap No. 376. FAO, Rome, p 27-58

*Harrison XA, Blount JD, Inger R, Norris DR, Bearhop S (2011) Carry-over effects as drivers of fitness differences in animals. J Anim Ecol 80:4-18

Hill RD (1994) Theory of geolocation by light levels. In: Boeuf L, Burney J, Laws RM (eds) Elephant seals: population ecology, behavior, and physiology. University of California Press, Berkeley, CA, p 227-236

*Hilton GM, Cuthbert RJ (2010) Review article: the catastrophic impact of invasive mammalian predators on 
birds of the UK Overseas Territories: a review and synthesis. Ibis 152:443-458

Hobson KA, Piatt JF, Pitocchelli J (1994) Using stable isotopes to determine seabird trophic relationships. J Anim Ecol 63:786-798

Igual JM, Forero MG, Tavecchia G, González-Solis J and others (2005) Short-term effects of data-loggers on Cory's shearwater (Calonectris diomedea). Mar Biol 146: 619-624

Imber MJ (1973) The food of grey-faced petrels (Pterodroma macroptera gouldi (Hutton)), with special reference to diurnal vertical migration of their prey. J Anim Ecol 42: 645-662

Jacoby WG (2000) Loess: a nonparametric, graphical tool for depicting relationships between variables. Elect Stud 19: 577-613

Jodice PG, Ronconi RA, Rupp E, Wallace GE, Satgé Y (2015) First satellite tracks of the Endangered black-capped petrel. Endang Species Res 29:23-33

Jueterbock A, Smolina I, Coyer JA, Hoarau G (2016) The fate of the Arctic seaweed Fucus distichus under climate change: an ecological niche modeling approach. Ecol Evol 6:1712-1724

Klages NTW, Cooper J (1997) Diet of the Atlantic petrel Pterodroma incerta during breeding at South Atlantic Gough Island. Mar Ornithol 25:13-16

Kokko H (1999) Competition for early arrival in migratory birds. J Anim Ecol 68:940-950

Krüger L, Paiva VH, Colabuono FI, Petry MV, Montone RC, Ramos JA (2016) Year-round spatial movements and trophic ecology of Trindade petrels (Pterodroma arminjoniana). J Field Ornithol 87:404-416

Krüger L, Ramos JA, Xavier JC, Grémillet D and others (2017) Identification of candidate pelagic marine protected areas through a seabird seasonal, multispecific and extinction risk-based approach. Anim Conserv 20:409-424

*Leal GR, Furness RW, McGill RA, Santos RA, Bugoni L (2017) Feeding and foraging ecology of Trindade petrels Pterodroma arminjoniana during the breeding period in the South Atlantic Ocean. Mar Biol 164:211

Lescroël A, Ballard G, Toniolo V, Barton KJ, Wilson PR, Lyver PO, Ainley DG (2010) Working less to gain more: when breeding quality relates to foraging efficiency. Ecology 91:2044-2055

Lewison R, Oro D, Godley B, Underhill L and others (2012) Research priorities for seabirds: improving seabird conservation and management in the 21st century. Endang Species Res 17:93-121

Kucas Z, MacGregor D (2006) Characterization and source of oil contamination on the beaches and seabird corpses, Sable Island, Nova Scotia, 1996-2005. Mar Pollut Bull 52: 778-789

Mackley EK, Phillips RA, Silk JRD, Wakefield ED, Afanasyev V, Furness RW (2011) At-sea activity patterns of breeding and nonbreeding white-chinned petrels Procellaria aequinoctialis from South Georgia. Mar Biol 158: 429-438

Maechler M, Rousseeuw P, Struyf A, Hubert M, Hornik K (2017) cluster: cluster analysis basics and extensions. $\mathrm{R}$ package version 2.0.6

Marine Conservation Institute (2017) MPAtlas. www.mpatlas. org (accessed 4 Jun 2017)

McMahon KW, Hamady LL, Thorrold SR (2013) A review of ecogeochemistry approaches to estimating movements of marine animals. Limnol Oceanogr 58:697-714
Navarro J, Votier SC, Aguzzi J, Chiesa JJ, Forero MG, Phillips RA (2013) Ecological segregation in space, time and trophic niche of sympatric planktivorous petrels. PLOS ONE 8:e62897

Norris DR, Marra PP (2007) Seasonal interactions, habitat quality, and population dynamics in migratory birds. Condor 109:535-547

Ojowski U, Editmann C, Furness R, Garthe S (2001) Diet and nest attendance of incubating and chick-rearing northern fulmars (Fulmarus glacialis) in Shetland. Mar Biol 139:1193-1200

Olmos F (2002) Non-breeding seabirds in Brazil: a review of band recoveries. Ararajuba 10:31-42

Olmos F, Bugoni L, Neves T, Peppes F (2006) Caracterização das aves oceânicas que interagem com a pesca de espinhel no Brasil. In: Neves T, Bugoni L, Rossi-Wongtschowski CLB (eds) Aves oceânicas e suas interações com a pesca na Região Sudeste-Sul do Brasil. Instituto Oceanográfico - USP, São Paulo, p 37-67

Orgeira JL (2001) Nuevos registros del petrel Atlántico (Pterodroma incerta) en el océano Atlántico Sur y Antártida. Ornitol Neotrop 12:165-171

* Orgeira JL, Scioscia G, Torres MA, Dellabianca NA (2013) New at-sea records of pelagic seabirds in the South Atlantic Ocean and Antarctica. Polar Res 32:18972

* Passos C, Navarro J, Giudici A, González-Solís J (2010) Effects of extra mass on the pelagic behavior of a seabird. Auk 127:100-107

Perez MS, Daudt NW, Tavares M, Ott PH, Santos RA, Fontana CS (2019) Diet of the Atlantic petrel Pterodroma incerta during the non-breeding season. Mar Ornithol 47:43-47

Phillips RA, Xavier JC, Croxall JP (2003) Effects of satellite transmitters on albatrosses and petrels. Auk 120: 1082-1090

* Phillips RA, Silk JRD, Croxall JP, Afanasyev V, Briggs DR (2004) Accuracy of geolocation estimates for flying seabirds. Mar Ecol Prog Ser 266:265-272

* Phillips SJ, Anderson RP, Schapire RE (2006) Maximum entropy modelling of species geographic distributions. Ecol Modell 190:231-259

Phillips RA, Bearhop S, Mcgill RAR, Dawson DA (2009) Stable isotopes reveal individual variation in migration strategies and habitat preferences in a suite of seabirds during the nonbreeding period. Oecologia 160:795-806

*Phillips RA, Lewis S, González-Solís J, Daunt F (2017) Causes and consequences of individual variability and specialization in foraging and migration strategies of seabirds. Mar Ecol Prog Ser 578:117-150

*Philpot SM, Lavers JL, Nugegoda D, Gilmour ME, Hutton I, Bond AL (2019) Trace element concentrations in feathers of seven petrels (Pterodroma spp.). Environ Sci Pollut Res Int 26:9640-9648

* Pinet P, Jaquemet S, Pinaud D, Weimerskirch H, Phillips RA, Le Corre M (2011a) Migration, wintering distribution and habitat use of an endangered tropical seabird, Barau's petrel Pterodroma baraui. Mar Ecol Prog Ser 423: 291-302

* Pinet P, Jaeger A, Cordier E, Potin G, Le Corre M (2011b) Celestial moderation of tropical seabird behavior. PLOS ONE 6:e27663

Quillfeldt P, Masello JF, Navarro J, Phillips RA (2013) Yearround distribution suggests spatial segregation of two small petrel species in the South Atlantic. J Biogeogr 40: 430-441 
R Core Team (2017) R: a language and environment for statistical computing. R Foundation for Statistical Computing, Vienna

Ramírez I, Paiva VH, Menezes D, Silva I, Phillips RA, Ramos JA, Garthe S (2013) Year-round distribution and habitat preferences of the Bugio petrel. Mar Ecol Prog Ser 476: 269-284

Ramos R, González-Solís J, Ruiz X (2009) Linking isotopic and migratory patterns in a pelagic seabird. Oecologia 160:97-105

Ramos R, Sanz V, Militão T, Bried J and others (2015) Leapfrog migration and habitat preferences of a small oceanic seabird, Bulwer's petrel (Bulweria bulwerii). J Biogeogr 42:1651-1664

Ramos R, Ramírez I, Paiva VH, Militão T and others (2016) Global spatial ecology of three closely-related gadfly petrels. Sci Rep 6:23447

Ramos R, Carlile N, Madeiros J, Ramírez I and others (2017) It is the time for oceanic seabirds: tracking year-round distribution of gadfly petrels across the Atlantic Ocean. Divers Distrib 23:794-805

Ramos R, Llabrés V, Monclús L, López-Béjar M, GonzálezSolís J (2018) Costs of breeding are rapidly buffered and do not affect migratory behavior in a long-lived bird species. Ecology 99:2010-2024

Rayner MJ, Hauber M, Clout M, Seldon D, Van Dijken S, Bury S, Phillips R (2008) Foraging ecology of the Cook's petrel Pterodroma cookii during the austral breeding season: a comparison of its two populations. Mar Ecol Prog Ser 370:271-284

Rayner MJ, Taylor GA, Gummer HD, Phillips RA, Sagar PM, Shaffer SA, Thompson DR (2012) The breeding cycle, year-round distribution and activity patterns of the endangered Chatham petrel (Pterodroma axillaris). Emu 112:107-116

Rexer-Huber K, Parker GC, Ryan PG, Cuthbert RJ (2014) Burrow occupancy and population size in the Atlantic petrel Pterodroma incerta: a comparison of methods. Mar Ornithol 42:137-141

Richardson ME (1984) Aspects of the ornithology of the Tristan da Cunha group and Gough Island 1972-1974. Mar Ornithol 12:123-201

Editorial responsibility: Sandra Hochscheid, Napoli, Italy
Ridoux V (1994) The diets and dietary segregation of seabirds at the subantarctic Crozet Islands. Mar Ornithol 22: $1-192$

Rodríguez A, Holmes ND, Ryan PG, Wilson K and others (2017) Seabird mortality induced by land based artificial lights. Conserv Biol 31:986-1001

* Rodríguez A, Arcos JM, Bretagnolle V, Dias MP and others (2019) Future directions in conservation research on petrels and shearwaters. Front Mar Sci 6:94

* Rousseeuw PJ (1987) Silhouettes: a graphical aid to the interpretation and validation of cluster analysis. J Comput Appl Math 20:53-65

*Simons R (2017) ERDDAP: NOAA/NMFS/SWFSC/ERD, Monterey, CA. https://coastwatch.pfeg.noaa.gov/erddap/ index.html (accessed 15 Sep 2017)

* Uhart MM, Gallo L, Quintana F (2018) Review of diseases (pathogen isolation, direct recovery and antibodies) in albatrosses and large petrels worldwide. Bird Conserv Int 28:169-196

UNESCO (2019) World Heritage List. Gough and Inaccessible Islands. https://whc.unesco.org/en/list/740 (accessed $28 \mathrm{Jul} 2019)$

* Votier SC, Fayet AL, Bearhop S, Bodey TW and others (2017) Effects of age and reproductive status on individual foraging site fidelity in a long-lived marine predator. Proc R Soc B 284:20171068

*Wanless RM, Angel A, Cuthbert RJ, Hilton GM, Ryan PG (2007) Can predation by invasive mice drive seabird extinctions? Biol Lett 3:241-244

*Wanless RM, Ratcliffe N, Angel A, Bowie BC and others (2012) Predation of Atlantic petrel chicks by house mice on Gough Island. Anim Conserv 15:472-479

Warham J (1996) The behaviour, population biology and physiology of the petrels. Academic Press, London

* Wood SN, Augustin NH (2002) GAMs with integrated model selection using penalized regression splines and applications to environmental modelling. Ecol Modell 157: 157-177

* Yamamoto T, Takahashi A, Yoda K, Katsumata N, Watanabe S, Sato K, Trathan PN (2008) The lunar cycle affects at-sea behaviour in a pelagic seabird, the streaked shearwater, Calonectris leucomelas. Anim Behav 76:1647-1652

Submitted: March 1, 2019; Accepted: September 13, 2019 Proofs received from author(s): November 7, 2019 